Pobrane z czasopisma Annales H - Oeconomia http://oeconomia.annales.umcs.pl Data: 26/04/2023 12:26:58

DOI:10.17951/h.2017.51.2.97

\begin{tabular}{lc}
\hline \multicolumn{1}{c}{ A N N A L E S } \\
UNIVERSITATIS MARIAE CURIE-SKŁODOWSKA \\
LUBLIN - POLONIA \\
VOL. LI, 2 \\
\hline
\end{tabular}

University of Łódź, Faculty of Management

WOJCIECH GRZEGORCZYK

wgrzegorczyk@uni.lodz.pl

\title{
New Marketing Concepts in Marketing Strategies on International Markets
}

Nowe koncepcje marketingu w strategiach marketingu międzynarodowego

Key words: marketing strategies; international marketing

Słowa kluczowe: strategie marketingowe; marketing międzynarodowy

JEL code: M31

\section{Introduction}

The selected new marketing concepts (Agile Marketing, Blue Ocean Strategy) are discussed in the literature on the subject without being related to the company's activities on international markets. Furthermore, the critical analysis of these concepts is very rarely provided. That is why the aim of this article is to present the possibilities to use them to create and implement new marketing strategies in companies operating on international markets. This refers to the evaluation and selection of international markets, the choice of international expansion forms, the selection of marketing instruments and their use in practice. The article is an attempt to present a critical evaluation of those new marketing concepts and the possibilities to use them at subsequent stages of marketing strategies on international markets. The article presents a critical analysis of those concepts based on the subject literature. 


\section{The importance of marketing research in the process of expansion into foreign markets}

The most common form of the business strategy of operating on international markets is the model of internationalisation represented by the Universities in Uppsala and Helsinki. The process begins with the research on international markets and then the company evaluates and selects the foreign market or markets that it intends to enter. The next stage is to take decisions as to the form of expansion. There are many ways of expansion that may be taken into account ranging from different forms of export through various types of cooperation with or without joint capital to direct investments [Rymarczyk 2004, pp. 152-160; Grzegorczyk 2013, pp. 79-110; Fonfara 2014, pp. 45-50; Gorynia 2007, pp. 63-73]. Having chosen the form of expansion, the company develops the marketing mix strategy and other functional strategies. The last stages of the process involve implementing the strategies and reviewing the assumed aims.

As it has already been emphasised, the fundamental condition that determines the decision to expand into foreign markets is to conduct the in-depth market research of those markets. It should be emphasised that the research on international markets is expensive and time-consuming. On the other hand, it is also necessary, as the company intends to enter the international markets that it has not been operating on before [Wiktor et al. 2008, pp. 40-78; Grzegorczyk 2013, pp. 27-32]. Conducting in-depth research allows the company to reduce the risk of selecting an unsuitable market or preparing the marketing strategy in an inappropriate way and, as a result, to avoid failure on international markets. The findings of the research should be stored in databases which are the elements of the company's Marketing Information System. If the company operates in accordance with the Helsinki internationalisation model it will take decisions concerning its further expansion into other international markets after it has achieved the intended marketing goals. In order to reduce its risks and costs the company starts the market research on other foreign markets, which does not generate as big costs as the ones incurred when the international market research was conducted for the first time as both the research methodology and research tools have already been used and the company is familiar with them. The company, therefore, has access to the evaluation of other foreign markets and it just needs some additional research using the most recent data. There is no doubt, however, that in order to expand into foreign markets the company needs to conduct marketing research on those markets in a reliable and diligent way. It should be also emphasised that the method used to prepare and implement the research process is the sequential method, which involves dividing tasks into particular stages and makes it possible to eliminate errors in the research process. 
Pobrane z czasopisma Annales H - Oeconomia http://oeconomia.annales.umcs.pl Data: 26/04/2023 12:26:58

\section{Assumptions of the Agile Marketing concept}

The Agile Marketing concept has been derived from information technologies and its main principles were defined in the so-called Agile Manifesto announced in 2001 in the USA. The main idea behind the Agile Manifesto is that designing software is based on disciplined project management, which assumes that the expectations and solutions concerning the assumed goals frequently change and, as a result, the applied tools are being adapted on a regular basis. The whole project is divided into particular tasks carried out by independent teams taking decisions as to how to pursue the goals. The teams contact each other and present their findings, which allows them to introduce possible changes into their actions [Kalińska-Kula 2016, pp. 2-4].

The above presented principles of the Agile Manifesto were relatively quickly transferred to the area of marketing and the term "Agile Marketing" was introduced. According to Agile Marketing, it is more important to react to changes than to implement closely the previously determined tasks. All the actions should be as flexible as possible and their effects should be measured. Therefore, the marketing staff should determine what the desired effects of a particular marketing activity are and what indicators should be used to measure them. It is also necessary to determine how to act when the assumed goals are not being achieved and what goals the company can achieve if it has changed its goals as a result of the changes taking place in its environment. If the company wants to be able to act in a flexible way it should regularly determine to what degree its goals have been achieved. In order to do that the company should collect the market information concerning particular actions on a regular basis, i.e. to collect the data while implementing particular strategies. This will enable the company to modify its actions.

These assumptions should cause changes in the marketing research process. Their main aim is to make the research process quick and relatively inexpensive. The research should be conducted in an "agile way" so that the information from the market can be acquired and used quickly to make marketing decisions as soon as possible [www.ispro.pl/blog/agile-marketing-przyszlosc-czy-utopia]. Such assumptions imply that it is necessary to monitor the market permanently in order to undertake marketing actions and to identify the results and effects of these actions on a permanent basis. It is assumed that in order to do that, instead of big cross-sectional studies, we can make use of a big number of quick, brief tests and simple experiments and to cooperate with potential buyers of our products on a regular basis. The process of cooperation with potential buyers can take place on the Internet, which is an interactive communication channel, and can give us access to the information that concerns not only the sales of particular products but also the interests of buyers, their attitude towards products, their opinions, behaviours and buying motives. The Internet also enables companies to conduct both quantitative and qualitative research, it reaches respondents and gives access to their feedback quickly and, what is more, the costs of research are relatively low. The Internet also enables them to analyse the 
collected data immediately with the use of data warehouses and information systems, such as DMMS (Data Mining Management System) or OLAP (Online Analytical Processing) [Kalińska-Kula 2016, pp. 4-7; Halligan and Shah 2010, pp. 25-28].

\section{Possibilities of using Agile Marketing to expand into foreign markets}

The Agile Marketing concept does not seem to be an original idea as it essentially repeats the basic assumptions of traditional marketing, according to which, the company should operate in a flexible way and to immediately adapt to the changing conditions of its environment. The authors of Agile Marketing claim that in traditional marketing the implementation of particular elements of a project commissioned by a client, according to the client's requirements (such as promotional campaigns, launching a new product, etc.), requires following closely the adopted plan step by step. It is supposed to make it impossible to provide for and implement changes during the process of accomplishing the project goals. In Agile Marketing, by contrast, the most important element are clients and their requirements, plans of action are immediately revised following the changes observed in the company's environment. The criticism that in traditional marketing it is impossible to accommodate the changing needs of a client is not, in fact, justified as changes can be implemented if such an assumption has been accepted during the process of negotiation with the client. Another assumption of traditional marketing states that the data necessary to measure the effectiveness and efficiency of particular marketing activities (e.g. the promotional campaign) is collected and analysed after the activity has been completed, as a result of which the process lacks flexibility and it is not possible to introduce changes into it. In fact, making a big distinction between traditional marketing and Agile Marketing is evidently wrong as the necessity to conduct research and collect data concerning the effects of marketing activities in the course of these activities and not afterwards was already recognised in Polish publications on the subject in the 1980s [Dietl 1986, pp. 160-171].

The literature on Agile Marketing also emphasises that "Agile Marketing Research" has a key advantage over traditional marketing research as it is conducted on the Internet and thanks to that the collected data can be analysed in depth. This opinion does not seem to be fully convincing. The literature on the subject even coined a special term for it - the Internet marketing. Thus, the Internet can be also used in the so-called traditional marketing activities.

As it has already been emphasised Agile Marketing prefers short, quick and cheap tests and regular current observation of the market to sequential analysis. This kind of tests are useful if they are being carried out in the course of the marketing strategy implementation. It seems, however, that they are most suitable for promotion research, communication with clients and the evaluation of clients' reactions to the launch of new products being, among others, sold online. 
In view of the above couple of comments concerning Agile Marketing limitations, we have to admit that Agile Marketing activities are, undoubtedly, to a certain extent, innovative and they should be used to prepare and implement marketing strategies [Małus 2014, pp. 4-5]. They are, however, complementary and auxiliary activities concerning rather data collection and analysis techniques and some selected elements of marketing research and strategies. Therefore, it should be determined whether Agile Marketing can be used in marketing activities on international markets, and if so, in what area.

As it has already been emphasised before the first stage of the company's marketing strategy development on international markets is to evaluate and select one or more foreign markets that the company wants to enter. It can be done, as it has been mentioned above, through international market research concerning the market structure and its economic situation. Such research, particularly market structure research, should be, however, extensive, thorough and conducted mainly on the basis of secondary literature. The reason for that is that the findings of international market research on the market structure and the economic situation on the market allow the company to take a decision as to which market or markets it intends to enter and such a decision cannot be based on short, quick and random tests. The decision to select a particular foreign market has an impact on subsequent marketing activities and if the company's choice is wrong it can be forced to withdraw from the foreign market in spite of the incurred costs. One of the sources of the structural market research information that is very intensively used, as it can also be observed in sequential analyses, is the Internet so it is not just a domain of Agile Marketing. The research on market business situation also uses secondary literature but it is complemented with primary research, which mostly concerns the acceptance of foreign products by customers on international markets, customers' attitude to particular brands, etc. Therefore, it can be admitted that at the stage of foreign market evaluation and selection the use of Agile Marketing, particularly in the area of Agile Research, is not necessary. It can be used, however, to conduct research on the economic situation concerning customers' behaviour.

The selection of a form of expansion uses mainly the information concerning the legal system on international markets, regulations on foreign investments and their protection, patent protection, the possibilities to transfer potential profits, state policy on foreign trade, terms of payment in international transactions, etc. In all these areas the information collected comes from secondary sources, particularly from the Internet and databases available. Therefore, there is no need to take actions from the area of Agile Marketing.

The next stage of the international marketing strategy involves determining the content of marketing-mix strategy, the major part of which is determined by comparing activities of the most important competitors on foreign markets. This comparing process uses benchmarking in the areas of: product policy, pricing, development and use of distribution channels as well as promotional and communication activities. 
There is little scope here for the use of Agile Marketing, which can only refer to such issues like, for example, the acceptance rate of foreign brands and opinions on competitors' products. Agile Marketing is just complementary to basic sequential market analysis concerning, in this case, the product. The products to be launched on a foreign market in terms of structure, quantity and functions cannot be determined with the use of piecemeal research. Agile Research can be used only when the marketing strategy started to be implemented, particularly when the company is in a position to introduce genuine innovations. If the company resigns from or delays innovations it could incur very high alternative costs (potentially lost benefits). In such case, Agile Marketing research can give quick information about the demanded quantity of the product and, as a result, it may allow the company to take a decision to eventually introduce these innovations onto the market at once.

As regards pricing policy it is necessary to have information about the level and structure of market prices, price changes and forecasts, their flexibility, etc. and Agile Research cannot provide this sort of information. Preparing activities in the area of distribution requires access to data about the distribution channels, forms of physical distribution and the distribution share and forms of the biggest market players. This sort of data can be sourced from secondary statistical and descriptive sources, the Internet databases or the observation of foreign markets and it does not help to use Agile Research to get access to this kind of information. Similarly, Agile Research is not useful for developing promotional activities on foreign markets. Generally, the company is not able to prepare a promotional program on its own. What is of key importance, however, for the development of promotional activities on international markets, is the information concerning promotions of the major market players, their costs, the message content, etc. This kind of information is generally acquired from secondary sources, such as the Internet, professional magazines or market observation.

The next stage of the marketing strategy on international markets is to implement the strategy. According to traditional marketing assumptions, the marketing strategy implementation should be monitored. The company should acquire information about the extent to which marketing goals have been achieved and about the marketing strategy effects. This information should be collected both during the process of strategy implementation and after it. Collecting current information on a regular basis is characteristic for the Agile Marketing concept but it should be emphasised that it also follows general marketing principles. In my opinion, both Agile Marketing and traditional marketing procedures should be implemented in order to determine the effectiveness and efficiency of the marketing strategy on the international market. Agile Research can be used during the process of strategy implementation mainly due to the fact that it is cost-effective and gives a possibility to introduce quick strategy changes. In order to collect in-depth information about the market situation and sales process, however, the procedures of sequential analysis should be implemented simultaneously. This will make it possible to determine the effectiveness and efficiency of marketing activities on international markets. 


\section{Blue Ocean Strategy and its use in international marketing}

Blue Ocean Strategy was developed by Chan Kim and Mauborgne in 2005 [Chan Kim and Mauborgne 2005]. According to this theory, the market competition is becoming increasingly intensive and a lot of companies cannot endure its consequences. Such markets have been defined as the Red Ocean. While competing on these markets it is necessary to eliminate other competitors. This kind of competition involves exploiting the existing demand and groups of current buyers. In order to survive and to operate effectively in the future, companies should find the Blue Ocean - i.e. a new market space that has not been contested yet. The Blue Ocean is a marketplace where the company does not compare itself with other competitors as they are not present there. Instead of this, the company operates according to the so-called value innovation, which means it develops new products for new buyers. In order to create the Blue Ocean marketplace, companies can search for industries that are an alternative to the ones already existing, offer complementary products, look for potential buyers in the groups that buy some particular product very rarely or do not buy it at all.

The principles of the Blue Ocean strategy presented here just slightly diverge from Ansoff's division of growth strategies developed decades ago [Garbarski et al. 1998, pp. 108-118].

One of the strategies identified on the basis of two variables - i.e. the product and the market, on which the company operates - is the innovation (diversification) strategy, in which the company offers new products on new markets. The company develops thanks to the fact that it moves away from its current offer and its way of production as well as from the current market. The company can become successful following either of the two strategies if it offers truly new products (value innovation) on new markets. In my opinion, the Blue Ocean strategy can be implemented on international markets. It is conditioned, however, by a number of factors. The company should have the experience of operating on foreign markets, it should have high-quality research and development background and the skills to conduct marketing research on international markets as well as big financial resources. These factors can help to create innovations and find new markets (blue oceans) outside their home country. Doing that is very difficult, however, because in today's times the Red Ocean marketplaces are predominant.

\section{Conclusions}

The process of development and implementation of marketing strategies on international markets should be based on marketing research conducted sequentially. The aim of the paper was to present a critical analysis of the selected new marketing strategies from the perspective of their use in the process of the development of international marketing strategies, particularly Agile Marketing and Blue Ocean Strategy. Agile Marketing can be understood as a way to improve the organisation and 
technique of marketing research implementation and it is of little use in the process of the international marketing strategy development. It is mainly used at the stage of implementation and evaluation of marketing strategies on international markets. The Blue Ocean strategy, on the other hand, can be used to determine the content of the product policy and to select international markets.

\section{Bibliography}

Agile marketing - przyszłość czy utopia?, www.ispro.pl/blog/agile-marketing-przyszlosc-czy-utopia/ (access: 22.12.2016).

Chan Kim, W., Mauborgne, R., Strategia błękitnego oceanu, Wyd. MT Biznes, Warszawa 2005.

Dietl, J., Marketing, PWE, Warszawa 1986.

Fonfara, K. (ed.), Marketing międzynarodowy. Wspótczesne trendy i praktyka, PWN, Warszawa 2014.

Garbarski, L., Rutkowski, I., Wrzosek, W., Marketing, PWE, Warszawa 1998.

Gorynia, M., Strategie zagranicznej ekspansji przedsiębiorstw, PWE, Warszawa 2007.

Grzegorczyk, W., Marketing na rynku międzynarodowym, Wolters Kluwer, Warszawa 2013.

Halligan, B., Shah, D., Inbound Marketing. Get Found Using Google, Social Media, and Blogs, Helion, Gliwice 2010.

Kalińska-Kula, M., Agile Research - badania marketingowe wedtug filozofii zwinnego marketingu, "Studia Ekonomiczne Regionu Łódzkiego", no. 2, 2016, pp. 29-37.

Małus, K., Agile czy nie Agile - oto jest pytanie, "Strefa" no. 4, 2014, wyd. Project Management Institute Poland Chapter, pp. 4-5.

Rymarczyk, J., Internacjonalizacja i globalizacja przedsiębiorstwa, PWE, Warszawa 2004.

Wiktor, J.W., Oczkowska, R., Żbikowska, A., Marketing międzynarodowy. Zarys problematyki, PWE, Warszawa 2008.

\section{New Marketing Concepts in Marketing Strategies on International Markets}

The article deals with the new marketing concepts used to develop and implement marketing strategies for businesses on international markets. It mainly concerns the use of Agile Marketing and Blue Ocean Strategy. These concepts are discussed in marketing literature separately in a way that is not related to marketing strategies on international markets. Since they are entirely new concepts, the Polish literature on the subject very rarely presents their in-depth analysis or the possibilities to use them in international marketing and, therefore, these are the issues that the article deals with. The critical analysis of those concepts presented in this article is based on the literature of the subject and concerns the marketing research and subsequent stages of marketing strategies on international markets.

\section{Nowe koncepcje marketingu w strategiach marketingu międzynarodowego}

$\mathrm{W}$ artykule autor analizuje problem zastosowania nowych koncepcji marketingu w strategiach marketingu międzynarodowego. Odnosi się to do Agile Marketing i Blue Ocean Strategy. W literaturze polskiej problemy te są rzadko przedmiotem krytycznej analizy, a ponadto są omawiane odrębnie, bez ich związku z działaniem firm na rynkach międzynarodowych. Celem opracowania była próba ustalenia, czy i w jakim zakresie wyżej wskazane koncepcje mogą być zastosowane w marketingu międzynarodowym. Autor dokonał krytycznej analizy literatury przedmiotu właśnie z tego punktu widzenia, uwzględniając w szczególności badania marketingowe rynków międzynarodowych i elementy przeprowadzanej na nich strategii. 